\title{
Improving Quality of Alloys and Saving Alloying and Refining Additives While the External Cathode and Anode Are Exposed to the Melt in Constant Electric Field
}

\author{
Harast Aliaxandr Ivanavich \\ Department of Metals and Materials, Belarusian State University of Technology, Minsk, Belarus \\ Email address: \\ garost-51@tut.by \\ To cite this article: \\ Harast Aliaxandr Ivanavich. Improving Quality of Alloys and Saving Alloying and Refining Additives While the External Cathode and \\ Anode Are Exposed to the Melt in Constant Electric Field. Advances in Materials. Vol. 5, No. 6, 2016, pp. 66-72. \\ doi: 10.11648/j.am.20160506.12
}

Received: December 3, 2016; Accepted: December 19, 2016; Published: January 10, 2017

\begin{abstract}
The advanced methods for the alloy composition regulation at some consumption of slag-forming additives are suggested. When implementing the proposed technology, the slag functions as a protector and electric conductor, and redox processes are determined by the magnitude and the applied potential function. The cathodic and anodic polarization of aluminum alloys in alundum and graphite crucibles is studied with the curves polarization method. The behavior of components of aluminum alloys is studied under external cathodic and anodic effects of the melt with a constant electric field. During the cathode polarization there is a significant decrease of Mg loss in the aging process of the melt; on the contrary, anodic polarization increases the loss in comparison with the melting without external electrochemical action. The content of iron and nickel under anodic polarity of the melt is not reduced if it is compared to the melting without electrochemical action due to passivation. The elements at the end of the electrochemical series are mostly protected. Thus, copper, under the cathodic polarization, and especially the anodic one is wasted less.
\end{abstract}

Keywords: Off-Furnace Treatment, Melting, Melt, Slag, Electrode Polarization, Anode Effect, Potential, Current Density

\section{Introduction}

Several criteria, including the cost reduction per unit of production feature simultaneously the developed efficiency and innovation [1]. Recognition of the leading place of science in the evolution process objectively leads to focusing the attention on the challenging search field, so-called breakthrough areas; their implementation will fundamentally change the research area of modern science, will form new vectors of its development [2].

The difficult situation on the market of metal stock made commercial and technical service companies that produce alloys from metal scrap, to seek alternative materials and technologies [3].

The "micro-meso-macro" framework parameters of materials is established during the transition from liquid to solid state, i.e. from the beginning of the technological process; it requires new scientific and technological approaches to create a highly efficient technological breakthrough [4].
New materials and technologies produced on the base of breakthrough scientific developments at the Belarusian State Technological University can help effectively extract metals from a non-traditional types of charge (the iron-containing dust, sludge cupola gases, iron-containing sludge, scale, rust, grinding sludge, iron and steel turnings, wastes of facing materials and catalysts in the chemical and petrochemical industry) when a new class of reducing agents (atomic carbon and hydrogen) is used [5-8]. Reducing medium is formed by pyrolysis of polymer industrial wastes (plastics and elastomers) in the melt during the melting process when balled with polymers of metal-containing materials. This technology allows processing effectively fine concentrates, when atomic carbon and hydrogen provide a sufficient degree of extraction of metals even in the case of processing $\mathrm{Ti}, \mathrm{Zr}$, Hf oxides. Conventionally introduced structurally free carbon in the form of coke, graphite dust, and powdery charcoal does not promote metals reduction.

Study of compositions and structures of metal and slag 
melts their influence on melting technology, structure and quality of the product is one of the most important problems in metallurgy. The impact of various factors (i.e. medium of melting facility, slag composition, detrimental impurities, etc.) hampers to fully reach the predicted equilibrium in real metallurgical processes. At the same time, it is not always possible to accurately assess the contribution of a particular component within overall redox process in the system metalslag-gas (M-S-G). In addition to the main efficient causes of the metallurgical process, i.e. concentration gradient, there are closed-circuit microgalvanic cells at the boundary metal-slag that also determine the composition of the resulting alloy. However, the influence of the latter factor is insignificant because of the low electromotive force at the boundary M-S.

Considering the above mentioned reasons it is sound to use external electric fields to finish the melt directly in the melting facility, giving the alloy the required parameters, i.e. chemical composition and physical mechanical properties.

Electrochemical polarization of electrode in electroslag processes causes additional voltage drop when current is passed through the boundary M-S or M-S-G [9-10]. It may be due to a slow delivery of reagents to the phase boundary or electrochemical interaction [11].

There is a persistent practical interest in the proposed or already used methods of obtaining metals and their alloys by electrochemical decomposition of their oxides or oxyhalogenic melts. Available literature data relate mainly to studies on platinum electrodes [9] and carbon and graphite anodes [12-14].

The aim of this work is the study of the voltammetric behaviour of the melts based on aluminium with platinum and carbon and graphite electrodes and equimolar mixture of sodium and potassium chlorides as a flux. The study was to identify qualitative features of the process, to determine the modes and working parameters of the electrochemical action.

\section{Method}

The aluminum alloy of the following composition (\% wt.): $\mathrm{Si}-5.11 ; \mathrm{Fe}-0.79 ; \mathrm{Cu}-7.18 ; \mathrm{Mn}-0.20 ; \mathrm{Mg}-0.42 ; \mathrm{Ni}-$ $0.23 ; \mathrm{Zn}-0.40$ was subjected to polarization.

The equimolar mixture of salts $\mathrm{KCl}-\mathrm{NaCl}$ was used as a flux when the aluminum alloys were melted. Take into account that in the molten state the hypothetical density of the mixture of salts is not very different from the actual, since at operating temperatures the water absorption of the mixture is low.

When choosing the flux the following considerations were regarded:

- the density of the salt mixture in the molten state should not be more than $2.7 \mathrm{~g} / \mathrm{cm}^{3}$ to eliminate unwanted mixing of the melt and slag;

- salt should have low volatility;

- the melting point of the salt melt should not differ greatly from the melting temperature of aluminium and its alloys (not more than $150^{\circ} \mathrm{C}$ );

- the salt melt should not interact with the aluminium (cations of salts should be electronegative when compared to aluminum);

- the melt should not absorb moisture from air.

The studies were conducted in the temperature range 1023$1073 \mathrm{~K}$ in a three-electrode electrochemical cell (Figure.1) in a muffle furnace. The temperature was controlled by a platinum / rhodium thermocouple (S) within $\pm 2{ }^{\circ} \mathrm{C}$ range. A platinum wire served as a working electrode in alundum crucible, in the graphite one it was crucible itself; the surface contact with the melt determined the working density of the current.

The counter electrode was an unshielded carbon graphite core of $14 \mathrm{~mm}$ diameter; its submerged length was about 5$10 \mathrm{~mm}$, depending on the amount of slag. The amount of the sample salts that are "chemically pure" for the salt melt (for the flux) was weighed on the analytical balance (mass of the flux was approximately $1 / 5$ part by weight of the alloy being melted); it was on the molten aluminum alloy up to full melting of the mixture. A platinum wire of $0.5 \mathrm{~mm}$ diameter was used as electrode for comparison (quasi electrode); it was separated by the alundum bag from the working part of the cell. The latter was emerged into the melt and had a small hole of $2 \mathrm{~mm}$ diameter to provide electrolytic relation between the reference electrode and the working are of the cell. A nichrome wire, which had no contact with the working medium of the electrolytic cell served as current leads and connecting wires in an electric circuit, so as not to introduce impurities into the investigated melt. A prepolished copper plate served as a contact between the graphite crucible and nichrome; while operating it was slightly oxidized and it was periodically cleared.

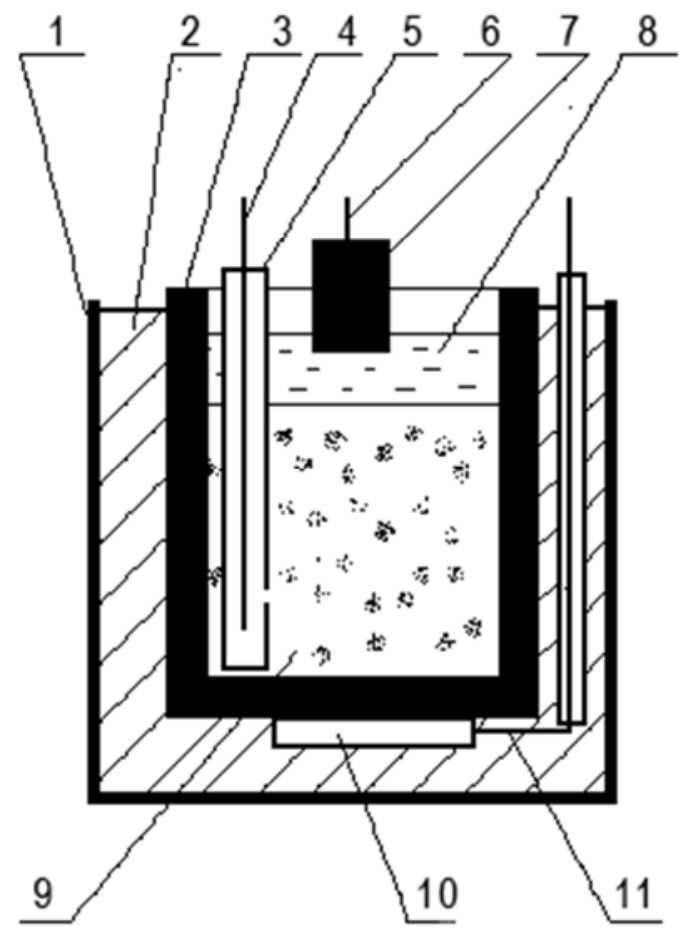

Figure 1. Scheme of the electrochemical cell.

1- stainless glass; 2 - asbestos insulation; 3 - carbon graphite crucible; 4 reference platinum electrode; 5 - alundum bag; 6 - current lead; 7 graphite counter electrode; 8 - slag; 9 - the investigated melt; 10 - copper plate; 11 - current lead. 


\section{Results}

The investigated melt is polarized with a power source B748 , with constant current loads and alternating polarity of the melt for a short time to establish permanent voltmeter indications to the reference electrode (polarization measurement) under galvanostatic conditions within 1-1. 5 hours.

Afterwards, the crucible was taken out of the furnace, the salt mixture was separately poured, and then aluminum alloy.

\subsection{Galvanostatic Polarization Study}

In this paper an attempt is made to assess the electrode polarization in the metal-slag system at these potentials under the galvanostatic conditions, taking into account the patterns of transition charges at the phase boundary [15-16] and the modern concepts of their multiple stages. The magnitude of the current density was calculated according to the surface border metal-slag. The I-E curve readings reflect the melt potential towards a platinum reference electrode and the I-U curve shows the voltage drop through the cell (Figure 2-5). The potential of the melt in the absence of electric field (stationary or quasi-equilibrium) did not exceed $50 \mathrm{mV}$ in different cases if compared to the reference platinum electrode. It was possible to assume that the ratio of oxidized and reduced forms of components to external polarization in the depth of the melt is small. The shift of the stationary potential after electrochemical action was insignificant to the initial values that also indicated the absence of any considerable passivation in the melt when slag was used.

During the cathodic polarization of the melt (Figure 2) in the area of the current working readings $10-11 \mathrm{~mA} / \mathrm{cm}^{2}$ a sharp double increase of voltage on the electrochemical cell is observed, the potential of the cathode is somewhat reduced. The rapid increase of voltage indicates that there is passivation of the anode, i.e. the ohmic component of the given current densities is increasing. This phenomenon is known in the electrolysis of ionic melts with coal or graphite anodes, and it is called the "anode effect". The occurrence of anode effect is preceded by anodic overvoltage, growing to the limit at which anode effect begins. A light strip was observed between the carbon anode and the electrolyte; it was characterized by a yellow glow and consisted of a mass of tiny sparks. During the anode effect the formation of gas bubbles ceases. The active complexes of chlorine and even $\mathrm{CCl}_{4}$ are formed in the electrolysis of molten chlorides [17].

The mechanism of chlorine ions discharge can be depicted as follows:

$$
\begin{gathered}
\mathrm{Cl}-+\mathrm{C}=\mathrm{CCl}+\mathrm{e} \\
\mathrm{CCl}+\mathrm{CCl}=2 \mathrm{C}+\mathrm{Cl}_{2} \\
\mathrm{CCl}+\mathrm{Cl}-=\mathrm{C}+\mathrm{Cl}_{2}+\mathrm{e} .
\end{gathered}
$$

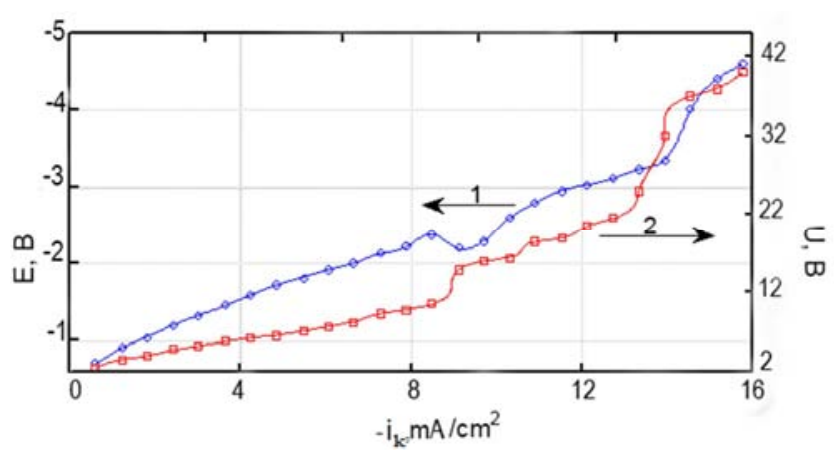

Figure 2. The catodic polarization of the melt in the alundum crucible (current leads are platinum).

1 - Melt potential relating to the platinum reference electrode; 2 - Total voltage decreases throughout the cell.

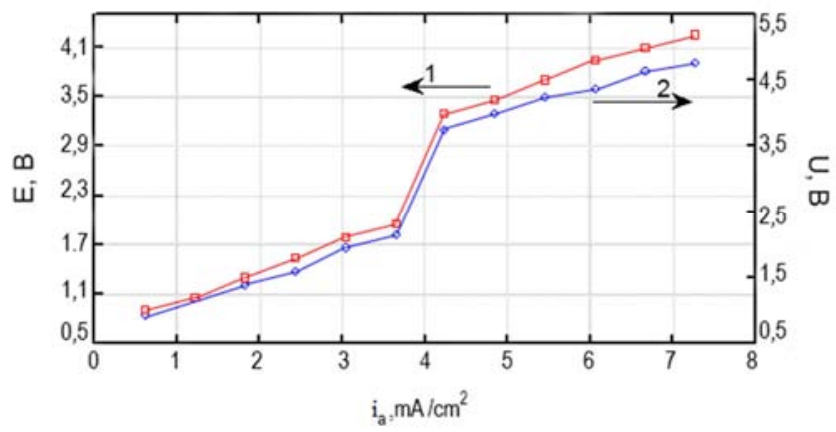

Figure 3. The anodic polarization of the melt in the alundum crucible (current leads are platinum).

1 - Melt potential relating to the platinum reference electrode; 2 - Total voltage decreases throughout the cell.

The formation of the film of the surface compounds of carbon with halogen $\left(\mathrm{C}_{\mathrm{x}} \mathrm{Cl}_{\mathrm{y}}\right)$ should be considered the basic cause of anode effect. When the surface is covered with this compound, there comes deterioration of the wettability of the electrode. It is necessary to specify the fact that the halides of carbon are insulators. Only the simultaneous manifestation of insulating properties and weak wettability of electrode may cause the anode effect. The study of these phenomena is the subject of many works [18-19], but it is still not fully explained. Since the anode effect is caused by a stable gas film, it is necessary to specify some aspects of experimental observations:

- increase of gas amount when current density increases;

- fairly intensive evaporation of molten slag;

- weak wettability of carbon and graphite electrode by the molten electrolyte;

- electrostatic effect retain the charged gas bubbles on the electrode surface.

In future when cathodic polarization of the melt is deeper (in the region of potentials less than $-3 \mathrm{~V}$ ), the voltage in the cell increases up to $40 \mathrm{~V}$ and higher. While on the cathodic curve the increase of the potential corresponds to $\mathrm{Ik}$, it is close to the limit. It may be due to the early discharge of ions at the beginning of the electrochemical series of the stress; their content is negligible. 
During anodic polarization of the melt (Figure 3) inert platinum electrodes increase the voltage in the cell proportionally to the increase in anode potential with increase of current density. However, in the region of potentials of about 1.5-3 V there is a sharp rise of the anode potential. This, in turn, may be associated with an anode effect of the molten liquid, as there is no sharp rise of voltage. In this case, one can only assume that there is a diffusion mode of oxidation of certain elements of silumin. Diffusion mode of oxidation of some melts is observed in the works [20-21]. The following experimental facts [22] are established:

- the anode effect occurs only on carbon and graphite anodes; it does not occur on the inert (platinum, gold) and soluble anodes;

- critical current density of the anode effect occurrence depends on the concentration of dissolved oxides, the electrolyte temperature and it grows with its increase;

- electrode wettability depends on the change of the working electrode surface and the surface tension of the electrolyte.

The latter may change as a result of electrolysis significantly due to changes in concentrations of components in oxidized and reduced states. Ions delivery in the liquid melt cannot be slowed down, so a further increase in the anode potential leads to increase in the ions concentration, able to discharge at the boundary M-S (for example Cl-).

Cathodic polarization curve of the melt in graphite crucible (Figure 4) shows that in the case of using cells carrying an electric current (the crucible functions as current lead), there is no restriction in the reduction process in the liquid metal. The increase in the current load corresponds to the steady rise of the cathode potential. However, as it can be seen from the curves in logarithmic coordinates (Figure 5) on the dependence $\operatorname{lgi}_{\mathrm{k}}-\mathrm{E}$ a few areas with extreme currents are observed, indicating a diffusive nature of some metal ions contained in the melt in small amounts $(\mathrm{Mg}, \mathrm{Mn})$. Diffusion phenomena at the electrodes in ionic melts are subjected to the same regulations as in aqueous solutions; however, due to high temperatures and relatively high values of viscosity, diffusion coefficients are often significantly different in magnitude.

In this case electrochemical overpotential is very little, as the current exchange $i_{o}$ for all metals amounts $5-33 \mathrm{kA} / \mathrm{cm}^{2}$ (in water solutions $\mathrm{I}_{\mathrm{O}}=10^{-2}-10^{-6} \mathrm{kA} / \mathrm{cm}^{2}$ ). The deviation of the potential from equilibrium is small, it amounts $2-30 \mathrm{mV}$.

It should be noted that using the graphite crucible is not observed at these current densities and anode effect, as there is a more uniform current distribution through the melt and the redox process occurs in the whole volume of liquid metal.

Passivation of the melt is observed in the anodic polarity of the melt in graphite crucibles (Figure 6-7) only under a significant polarization (above $100 \mathrm{~mA} / \mathrm{cm}^{2}$ ), i.e. the critical value of current density increases allowing to intensify the anodic process.

\subsection{The Behavior of Elements of the Aluminum Alloy Under External Electrochemical Impact}

To study the influence of the nature and polarity of the external electrochemical impact on the behavior of elements of the aluminum alloy, the melt was exposed for a long time at a constant operating current of $\mathrm{I}=25 \mathrm{~mA}$ or $1.56 \mathrm{~mA} / \mathrm{cm}^{2}$ considering the surface area of M-S. There is no passive state of melt under such an anode load. Polarization was carried out separately for cathode and anode polarity of the melt for 20, 40 and $60 \mathrm{~min}$. After casting and cooling the samples, the study of chemical composition (GOST (National Standard) 21132.1) was carried out (Figure 8-14).

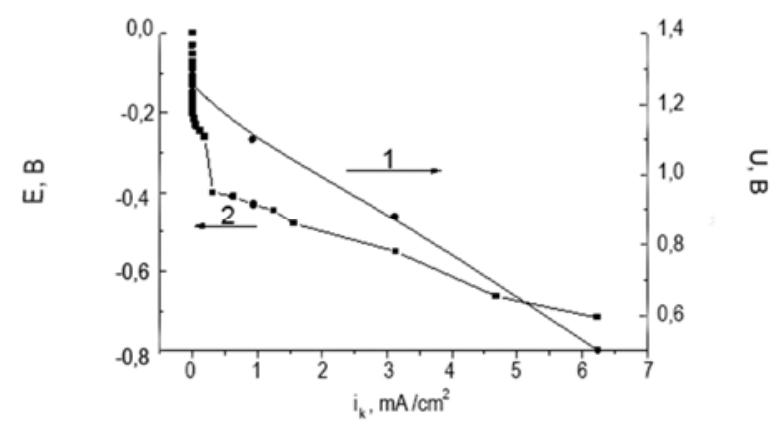

Figure 4. Cathodic polarization of the melt in the graphite crucibles.

1 - Melt potential relating to the platinum reference electrode; 2 - Total voltage decreases throughout the cell.

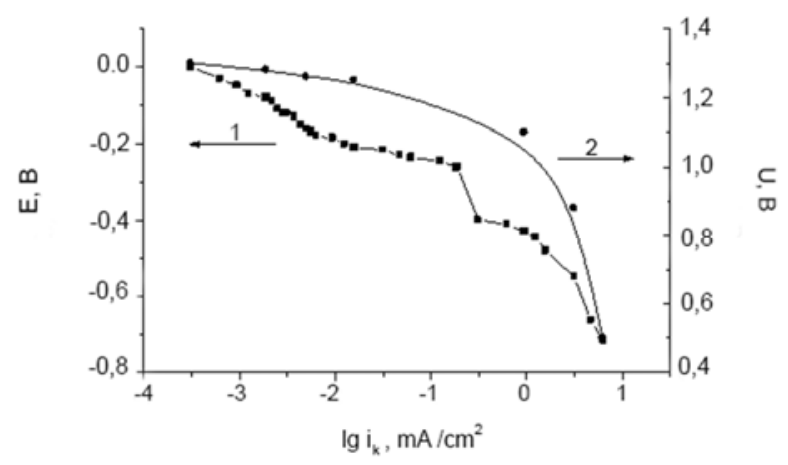

Figure 5. Cathodic curves in the logarithmic coordinates.

1 - Melt potential relating to the platinum reference electrode; 2 - Total voltage decreases throughout the cell.

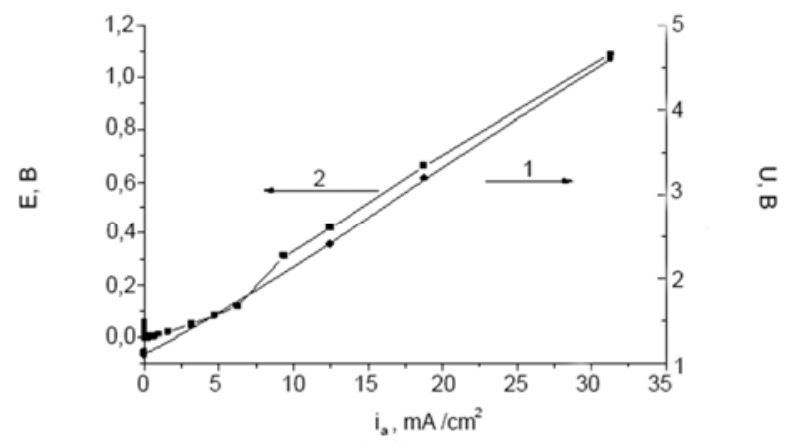

Figure 6. Anodic polarization of the melt in the graphite crucibles.

1 - Melt potential relating to the platinum reference electrode; 2 - Total voltage decreases throughout the cell. 


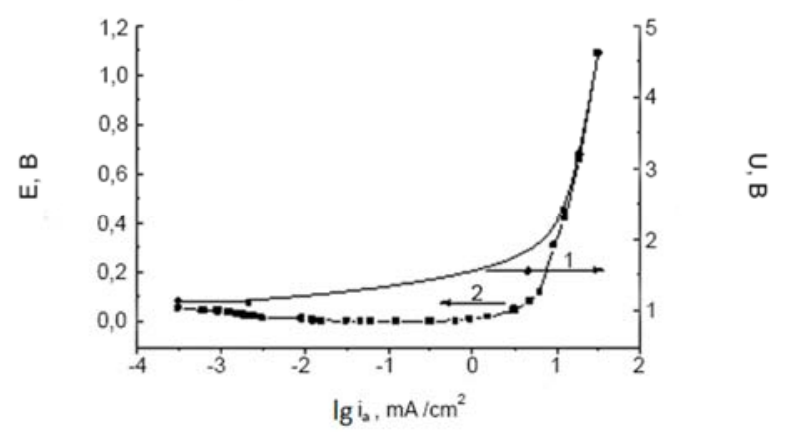

Figure 7. Anodic curves in the logarithmic coordinates.

1 - Melt potential relating to the platinum reference electrode; 2 - Total voltage decreases throughout the cell.

Metal waste (redistribution of the components between the melt and the slag) of the melt components at first approximation, is associated with their location in the electrochemical series of the stress.

The position of the metal in a series of voltage affects the ionic composition of the melt and temperature. In the absence of a single solvent, which is available in the case of using the aqueous solutions of the melts it is impossible to build a series of metals potentials. They can be built for melts and for individual metal salts with a common ion, or for metals in the melts of certain ion composition. The position of the metal in a series of metals potentials changes from one anion to another and, in some cases, depends on the temperature.

Electrochemical series of metals for the equimolar mixture $\mathrm{NaCl}-\mathrm{KCl}$ at $700^{\circ} \mathrm{C}$ :

$\mathrm{Mg}, \mathrm{Th}, \mathrm{U}, \mathrm{Mn}, \mathrm{Al}, \mathrm{Zr}, \mathrm{Ti}, \mathrm{Zn}, \mathrm{Cr}, \mathrm{Fe}, \mathrm{Pb}, \mathrm{Sn}, \mathrm{Co}, \mathrm{Cu}, \mathrm{Ni}$, $\mathrm{Ag}, \mathrm{Pt}, \mathrm{Au}$.

Under cathodic polarization (Figure 8) there is a significant reduction of $\mathrm{Mg}$ waste in the aging process of the melt, on the contrary, during anodic one there is increase of waste in comparison with the melting without external electrochemical action. Magnesium as an active metal will first be oxidized with anodic treatment. It should also be noted that changing the polarity of the melt can only reduce magnesium waste, but you can't completely eliminate it by increasing the duration of treatment.

This series can definitely be used in the analysis of components behavior in the slag, while the melt has a different ion composition, but the position of the elements in the series is nearly the same.

At first approximation, when the polarity of the aluminum melt is changed, the behavior of manganese (Figure 9) is similar to the behavior of magnesium. You can, however, note that under the cathodic polarity and increasing treatment duration, manganese can be saved from losses.

Zinc losses (Figure 10) under the anodic polarization, as well as under cathodic polarization are smaller than in the absence of electrochemical effects, and virtually the same.

Under the anodic polarity of the melt the iron content (Figure 11), nickel content (Figure 12) is not reduced if it is compared to the melting without electrochemical action, due to passivation.

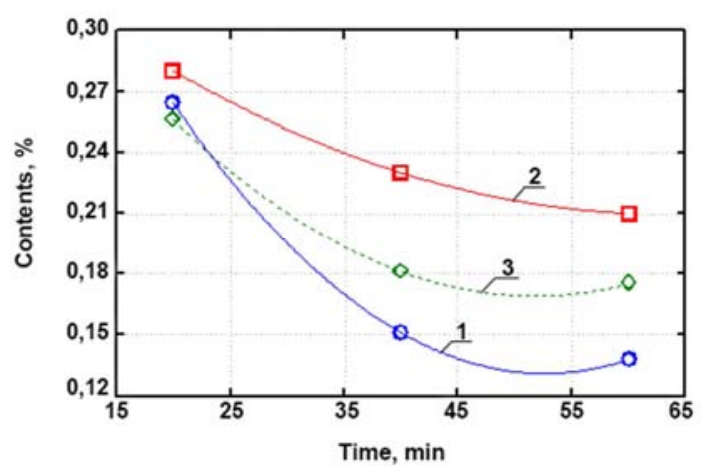

anodic polarization, 2- cathodic polarization, 3- no polarization

Figure 8. Magnesium content changes in the melt.

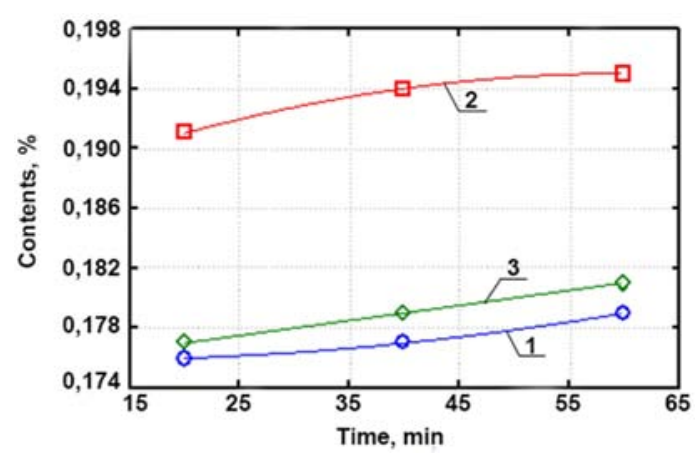

anodic polarization, 2- cathodic polarization, 3- no polarization

Figure 9. Manganese content changes in the melt.

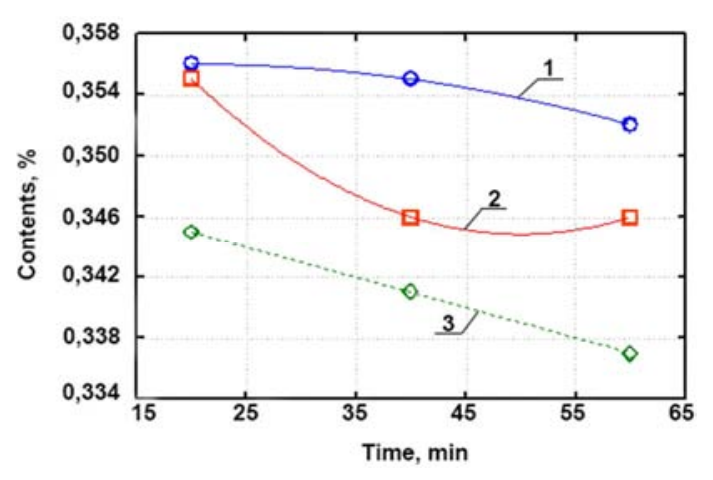

anodic polarization, 2- cathodic polarization, 3- no polarization

Figure 10. Zinc content changes in the melt.

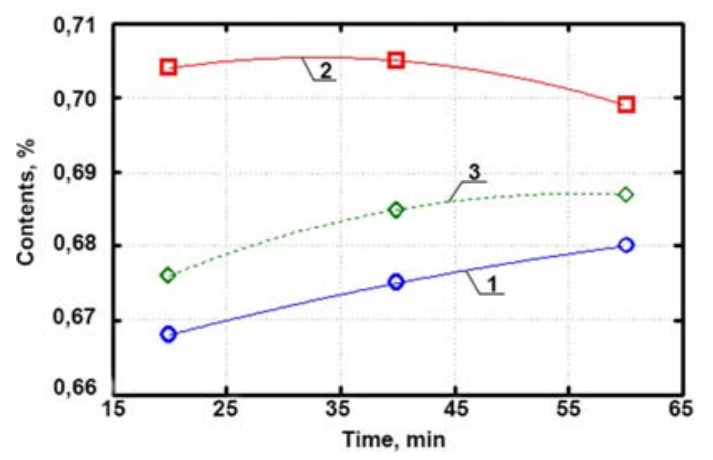

anodic polarization, 2- cathodic polarization, 3- no polarization

Figure 11. Iron content changes in the melt. 


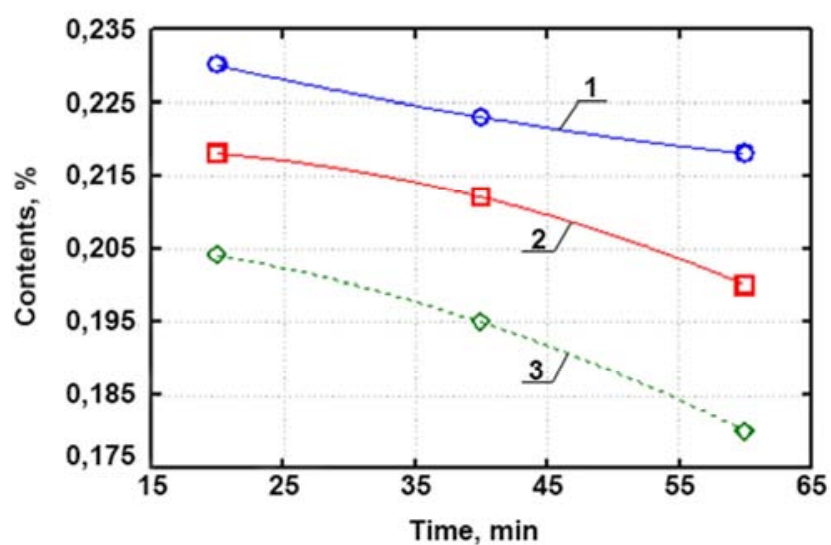

anodic polarization, 2- cathodic polarization, 3- no polarization

Figure 12. Nickel content changes in the melt.

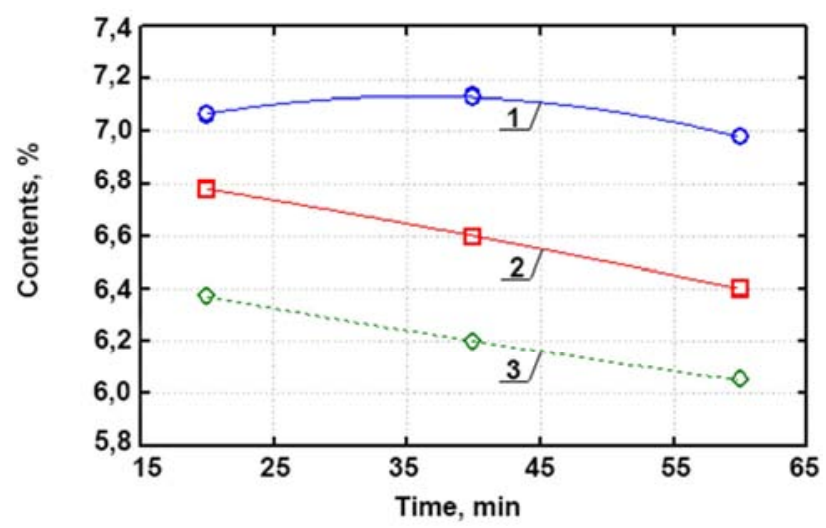

anodic polarization, 2- cathodic polarization, 3- no polarization

Figure 13. Copper content changes in the melt.

The greatest saving effect was observed for the elements at the end of the electrochemical potential series. Thus, copper, under the cathodic polarity, and especially under the anodic polarity (Figure 13) is wasted the least.

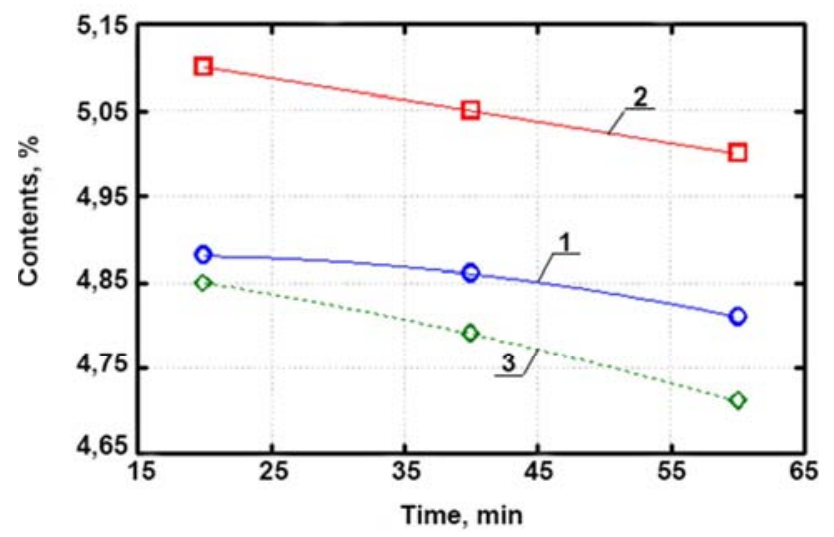

1-anodic polarization, 2- cathodic polarization, 3- no polarization

Figure 14. Silicon content changes in the melt.

Such components of the melt such as $\mathrm{Si}$ (Figure 14) is possible to save under the anodic exposure as well as and cathodic one to the melt.

\section{Discussion}

During the cathodic polarization of the melt in the area of the current working readings $10-11 \mathrm{~mA} / \mathrm{cm}^{2}$ a sharp double increase of voltage on the electrochemical cell is observed, the potential of the cathode is somewhat reduced. The rapid increase of voltage indicates that there is passivation of the anode, i.e. the ohmic component of the given current densities is increasing.

There are no any restrictions on the reducing process in the liquid metal on the cathodic polarization curve in a current conducting graphite crucible. The increase in the current load corresponds to the steady rise of the cathode potential. There are a few areas with extreme currents, indicating diffusive nature of the reduction of some metal ions that are present in the melt in small amounts $(\mathrm{Mg}, \mathrm{Mn})$.

The behavior of aluminum alloys components is investigated under external cathodic and anodic effects of the melt in the constant electric field. Metal waste (redistribution of the components between the melt and the slag) of the melt components at first approximation, is associated with their location in the electrochemical series of the stress. The position of the metal in a series of voltage affects the ionic composition of the melt and temperature. Under cathodic polarization there is a significant reduction of $\mathrm{Mg}$ waste in the aging process of the melt, on the contrary, during anodic one there is increase of waste in comparison with the melting without external electrochemical action. Magnesium as an active metal will first be oxidized with anodic treatment. It should also be noted that changing the polarity of the melt can only reduce magnesium waste, but you can't completely eliminate it by increasing the duration of treatment.

At first approximation, when the polarity of the aluminum melt is changed, the behavior of manganese is similar to the behavior of magnesium. You can, however, note that under the cathodic polarity and increasing treatment duration, manganese can be saved from losses. Zinc losses under the anodic polarization, as well as under cathodic polarization are smaller than in the absence of electrochemical effects, and virtually the same.

Under the anodic polarity of the melt the iron content, nickel content is not reduced if it is compared to the melting without electrochemical action, due to passivation.

\section{Conclusion}

Recognition of the leading place of science in the bulk of development factors determines focusing the attention on the problem search field, the so-called breakthrough areas, and their implementation will fundamentally change the research area and the conceptual structure of modern science, will form new vectors of its development. The characteristic features of development effectiveness and innovation must simultaneously be performed by several criteria, including reduction the cost reduction per unit of production. Delicate situation on the market of metal stock made commercial and technical service companies that produce alloys from metal 
scrap, to seek alternative materials and technologies.

New materials and technologies produced on the base of breakthrough scientific developments at the Belarusian State Technological University can help effectively extract metals from a non-traditional types of charge (the iron-containing dust, sludge cupola gases, iron-containing sludge, scale, rust, grinding sludge, iron and steel turnings, wastes of facing materials and catalysts in the chemical and petrochemical industry) when a new class of reducing agents (atomic carbon and hydrogen) is used. Reducing medium is formed by pyrolysis of polymer industrial wastes (plastics and elastomers) in the melt during the melting process when balled with polymers of metal-containing materials.

In the present study it is shown that influence of weak electric fields on the metal-slag and metal-slag-gas systems is able to intensify the redox processes. It is shown that it is possible to regulate the alloy composition at insignificant introduction of slag-forming additives. When implementing the proposed technology, the slag will perform mainly saving and electrically conductive functions, and the rate of redox processes is governed by the magnitude and sign of the applied potential.

\section{References}

[1] Korotckevich, A. V. Innovation Facilities in the Republic of Belarus A. I. Korotkevich, A. V. Kozlov, D. V. Shparun // Science and Innovations-2015. - № 11 (153)-P. 37-42 (in Russian).

[2] Honcharov V. Scietific breakthrough: problems of choice and implementation/. V. Honcharov // Science and Innovations 2015. - № 1 (143). - P. 43-47. (in Russian).

[3] Harast, A. I. Carbon iron alloys: structure formation and properties/ A. I. Harast. - Minsk: Belarus. Navuka, 2010. 252 p. (in Russian).

[4] Harast, A. I., Mazets A. F. "Method of Iron Smelting": Invention Patent of RB № 15409, 27.10.2011 (confirmed 29.07.2011) application a20100921, 17.06.2010 (IPC(2006.01) C21C1/00, C21C7/00, C25C7/00). (in Russian).

[5] Harast, A. I. Chemical Baling of Oily Cast Iron Turnings and Use of Bales to Substitute Expensive and Scarce Scrapes / A. I. Harast // International Journal of Materials Science and Applications. - 2013. - Vol. 2, No. 6. - PP. 194-203. doi: 10.11648/j.ijmsa.20130206.15.

[6] Harast, A. I. Modification and Microalloying of Iron Carbon Alloys Using Industrial Polymer Scrapes / A. I. Harast // Journal of Current Advances in Materals Sciences Research (CAMSR). - 2014. - Vol. 1, Issue 3. - PP. 66-74. www.vkingpub.com/journal/camsr/C American V-King Scientific Publishing.

[7] Harast, A. I. The Casting Technologies Focused on the Use of Industrial Waste and Semiprocessed Products Related to Engineering Industries / A. I. Harast // Journal of Multidisciplinary Engineering Science and Technology (JMEST), ISSN: 3159-0040.-2015. - Vol. 2 Issue 5. - PP. 914-918.
[8] Harast, A. I. Formation Mechanism Of Wear Resisting Surface Layer On Cast Iron Moulds By Direct Surface Alloying / A. I. Harast // Journal of Multidisciplinary Engineering Science and Technology (JMEST), ISSN: 31590040.-2015. - Vol. 2 Issue 9. - PP. 2591-2598.

[9] Kalmykov, V. A. Impact of thermoionic properties of slag on interphase processes in the system Gas-Slag- Metal / V. A. Kalmykov, P. Ja. Ageev // / High school news bulletin. Iron Industry. [Izv. vuzov. Chernaja metallurgija].-1969. - № 8. P. 10-13. (in Russian).

[10] Paton, B. E., Metallurgy of electroslag process / B. E. Paton, B. I. Medovar. Kiev: Navukova dumka, 1986.-247 p.

[11] Esin, O. A. Physical chemistry of pyrometallurgical processes. P. 2 / O. A. Esin, P. V. Gel'd. - M.: Metallurgija, 1966.-704 p. (in Russian).

[12] Grjotheim, K. Aluminium electrolysis / K. Grjotheim, C. Krohn, M. Malinovski. - Dusseldorf: AluminiumVerlagCmbH, 1982.-630 p.

[13] Haupin, W. E. Electrometallurgy of aluminium. / W. E. Haupin, W. B. Frank // Comprehensive treatise electrochemistry. - New York-London: Plenum Press.-1981. - Vol. 2. - P. 301-325.

[14] Vetjukov, M. M. Electrometallurgy of Aluminium and Magnesium / M. M. Vetjukov, A. M. Cyplakov, S. N. Shkol'nikov. - M.: Metallurgija, 1987.-320 p. (in Russian).

[15] Esin, O. A. Concentration polarization under high temperatures / O. A. Esin, G. A. Toporischev // Journal of Physical Chemistry. - 1957. - № 2. - P. 51-54. (in Russian).

[16] Ion exchange rate between liquid iron oxide melt / A. A. Plyshevskij, A. I. Sotnikov, O. A. Esin, L. N. Barmin // Electrochemistry. [Jelektrohimija].- 1968. - № 3. - P. 304306. (in Russian).

[17] Delimarskij, Ju. K. Kinetics of electrode processes in the melted salts / Ju. K. Delimarskij // Physical Chemistry of the melted salts and slags: International conference on physical chemistry. [tr. Vsesojuz. soveshh. po fiz. himii rasplavl. solej i shlakov], Sverdlovsk, 22-25 nov., 1960 / Academy of Sciences of the USSR, Ural Inst. of Electrochemistry [Akad. nauk SSSR, Ural. fil., In-t jelektrohimii]. - M., 1962. - P. 721. (in Russian).

[18] Antipin, L. N. Electrochemistry of the melted salts L. N. Antipin, S. F. Vazhenin. - M.: Metallurgizdat /, 1964.-365 p. (in Russian).

[19] Bajmakov, Ju. V. Electrolysis of the melted salts / Ju. V. Bajmakov, M. M. Vetjukov. - M.: Metallurgizdat 1965.-560 p. (in Russian).

[20] Popel', S. I., Theory of metallurgical processes: textbook for higher institutions S. I. Popel', A. I. Sotnikov, V. N. Boronenkov. - M.: Metallurgija /, 1986.-463 p. (in Russian).

[21] Interaction of the melt metal, gas, and slag: textbook / S. I. Popel', Ju. P. Nikitin, L. A. Barmin et al. - Sverdlovsk: UPI, 1975.-184 p. (in Russian).

[22] Delimarskij, Ju. K. Electrochemistry of ionic melts / Ju. K. Delimarskij. - M.: Metallurgija, 1978.-248 p. (in Russian). 